\title{
THE LEVEL OF PLASMA TESTOSTERONE DURING THE PRENATAL AND POSTNATAL PERIOD OF DEVELOPMENT IN BULLS
}

\author{
J. KOZUMPLÍK
}

Department of Farm Animal Reproduction and Surgery, University of Veterinary Science, 61242 Brno

Received fuly 24, 1980

\begin{abstract}
Kozumplík J.: The Level of Plasma Testosterone during the Prenatal and Postnatal Period of Development in Bulls. Acta vet. Brno 50, 1981: 27-32.

In order to establish testosterone in the blood plasma we employed the direct radioimmunological method with testosterone-labelled tritium. An examination of 44 fetuses was carried out during the prenatal period from the 190th to the 288th day of intrauterine development. On average we ascertained values of $1,145 \pm$ $\pm 0,73 \mathrm{nmol} / \mathrm{l}$, without any obvious relation to the age of the developing fetus. In the postnatal period an assessment was made of 57 bulls aged 47 to 106 days, and approximately $2,25 \pm 1,46 \mathrm{nmol} / 1$ plasma testosterone was ascertained, $\overline{\mathbf{x}} 23,04 \pm$ $\pm 19,81 \mathrm{nmol} / 1$ in 108 bulls aged 7 to 13 months, and $21,791 \pm 14,78 \mathrm{nmol} / 1$ in 154 bulls aged 2 and more years. The difference between the mean value of plasma testosterone in the prenatal period compared with all the assessed age categories in the postnatal period was significant $(P<0,01)$. In bulls aged 47 to 106 days the mean value of plasma testosterone compared with the values of other age categories, was also significantly lower $(P<0,01)$.
\end{abstract}

Bulls, testicular incretion, radioimmunoassay.

Recently a number of papers has been published on plasma testosterone in individual species of farm animals, determined with the help of the RIA method. The influence of the season on the level of plasma testosterone has been described in rams, goats, bulls and stallions, and in rabbits (Katongole et al. 1974; Schanbacher et al. 1976; Enbergs et al. 1977; Surd dby \& Tollman 1978). Many authors point out that in male individuals LH and testosterone are secreted into the blood in a pulsating, but irregular rhythm, and the level of testosterone depends on the influence of LH (Katongole et al. 1971; Sandford et al. 1976). Much work has also been directed to the establishment of the regularity of the rhythm of hormone production during the day in bulls, rams, boars and stallions (Ellendorf et al. 1975; Kattesh et al. 1979; Schan bacher et al. 1976; Smith et al. 1973). Also the influence of nutrition, body mass, and the size of the gonads on the level of plasma testosterone has been studied (Sitarz et al. 1977; Charala mbos 1979); the mutual relation of LH, FSH and testosterone (Schams et al. 1978; S und by et al. 1978) and between testosterone and the strength of the libido were compared (Foote et al. 1976). The effects of sexual excitement on the production of $\mathrm{LH}$ and testosterone have been investigated (Hruška et al. 1974). The results of many of the cited authors show that the fluctuation of the level of plasma testosterone appears irregularly irregular, a fact clearly shown by Kattesh et al. (1979) in boars. This fact makes difficult the comparison of mutual results in the papers of individual authors, and the formulation of the time schedule for production of a specific male sex hormone in various animal species.

In view of the fact that the occurrence of plasma testosterone has not yet been determined in male fetuses to a greater extent, we have included both the stage of prenatal development and certain periods of postnatal life in our observations. 


\section{Materials and Methods}

The direct radioimmunological method with testosterone-labelled tritium (Stupnicki 1975) was employed for determination of testosterone in the blood plasma of bulls. The experiment was carried out on 363 animals of various stages of prenatal and postnatal development.

The level of plasma testosterone was established in 44 fetuses from the 150th to the 288th day of intrauterine life. Further, the level of plasma testosterone was measured in 57 bulls aged 47 to 106 days (prepubertal stage), in 108 bulls aged 7 to 13 months (second phase of puberty), and in 154 bulls aged 2 years and more.

Blood was taken from the a. carotis in fetuses (after laparotomy in their mothers made for other experiments) and the last trimester of fetal development was covered over two- to five-day intervals. In the young bulls blood samples were taken from the jugular vein. Blood sampling was invariably carried out between 8 and 11 a. $\mathrm{m}$.

The Student's t-test and the Duncan test were employed for statistical evaluation of the results.

\section{Results}

In the prenatal period the level of plasma testosterone oscillated between 0.35 to $4.16 \mathrm{nmol} / 1$, without any special relation to the stage of development of the fetus. Out of 44 blood samples plasma testosterone (PT) was ascertained only in 2 cases $(4,5 \%)$ at a level of $3.47 \mathrm{resp} .4 .16 \mathrm{nmol} / 1$, and in 39 cases $(88,6 \%)$ it was lower than $1.73 \mathrm{nmol} / 1$. A mean value of $1.14 \pm 0.73 \mathrm{nmol} / 1$ was established (Table 1).

Table 1

Level of plasma testosterone in bulls at various stages of development

\begin{tabular}{|l|c|c|c|c|}
\hline \multicolumn{1}{|c|}{$\begin{array}{c}\text { Evaluated } \\
\text { period }\end{array}$} & Age & $\begin{array}{c}\text { Number of } \\
\text { Animals }\end{array}$ & $\begin{array}{c}\text { Testosterone } \\
\overline{\mathbf{x}} \mathrm{nmol} / \mathrm{l}\end{array}$ & $\mathrm{S}$ \\
\hline Prenatal & $\begin{array}{c}190-288 \\
\text { days }\end{array}$ & 44 & $\begin{array}{c}1.145 \\
0.347-4.164\end{array}$ & 0.73 \\
\hline Postnatal & $\begin{array}{c}47-106 \\
\text { days }\end{array}$ & $\begin{array}{c}7-13 \\
\text { months } \\
2 \text { and } \\
\text { more yrs }\end{array}$ & 108 & $\begin{array}{c}2.255 \\
0.347-5.205\end{array}$ \\
\hline
\end{tabular}

In bullocks aged $47-106$ days, i. e. in the prepubertal period, mean values of $2.25 \pm 0.42 \mathrm{nmol} / 1$ were established, thus significantly differing $(P<0,01)$ from the prenatal period. In the given time interval lasting higher PT values from day 68 were found. Up to day 67 the PT values $\bar{x}=1,11 \pm 0,69 \mathrm{nmol} / 1$ had been ascertained, and from day 68 they were $\bar{x}=2,74 \pm 1,32 \mathrm{nmol} / 1$.

Bulls aged 7 to 13 months, i. e. presenting a period designated as the second pubertal phase, ending with the first semen collection, formed the third group. A characteristic note of the whole group was the relatively great variety of the ascertained values of PT $(1.73$ to $91.95 \mathrm{nmol} / 1)$. Contrary to the prepubertal period, conspicuously higher mean values $\bar{x}=23.04 \pm 19.81 \mathrm{nmol} / 1$ were ascertained, these being statistically very significant differences $(P<0,01)$. The level of the PT was studied within this group in bulls aged 7-10 months (24 animals) and here we found the highest levels amongst the groups under consideration $\bar{x}=34.12 \pm 13.69 \mathrm{nmol} / 1$. The values reported here have also been considered 
from other viewpoints, and have been published in this paper as a preliminary study.

In the last age category there were 154 bulls, mostly aged $2-4$ years, a smaller number being older. The mean value of the PT very nearly agrees with the last-named group $(\bar{x}=21.79 \pm 14.78 \mathrm{nmol} / \mathrm{l})$. In this group too, one may observe a certain unsteadiness in the extreme values of PT, this, however, being characteristic of all the age categories, studied in this paper. A mutual comparison of the PT values, ascertained in our experiments, is to be found in Table 1, and the statistical elaboration of the values obtained is reported in Table 2.

Table 2

Statistical significance of differences in values of plasma testosterone during the studied periods of development

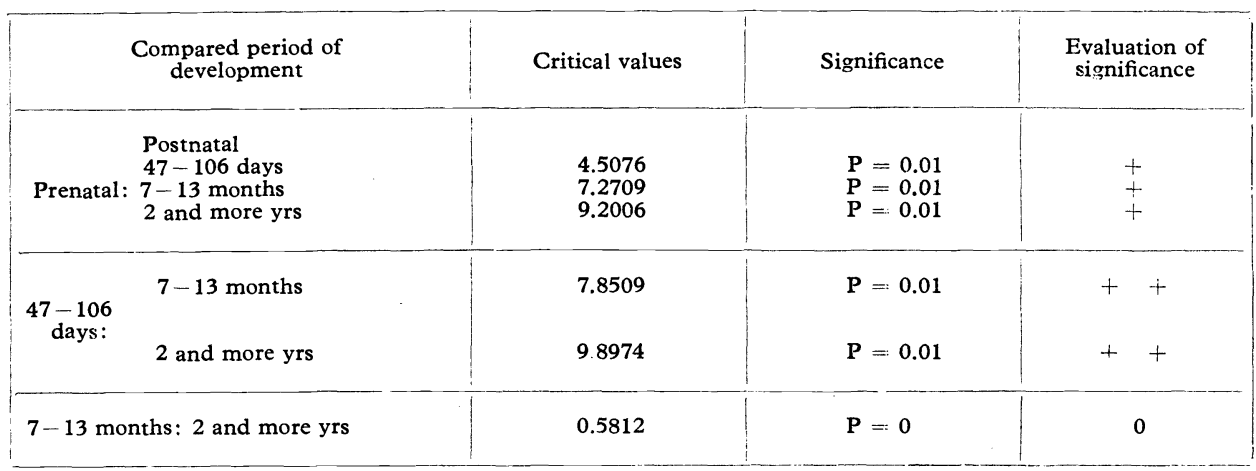

+ to the disadvantage of the prenatal period

++ to the disadrantage of the prepubertal neriod ( $47-106$ days of age)

\section{Discussion}

The levels of PT during fetal development were studied in detail in pig (Meusy and Dessolle 1975) and guinea pig (Pelardy and Delost 1977), in part also in children (For est et al. 1974). Whilst an increase in testosterone was registered between the 52 nd and the 60 th day of intrauterine development as well as a significant fluctuation of testosterone about the time of birth in the pig, an increase in the level of PT was found in the period around birth in the guinea pig and in prematurely born children. Our paper has not included the early period of development of the fetus of male cattle, but a sufficient number of ceses in the final 2 months of intrauterine development indicates no changes in fluctuation of the level of PT, which could be brought into connection with approaching parturition. In principle the ascertained levels of PT are markedly low and do not differ from the levels found in guinea pigs.

The period between the 47th and the 106th day post-partum agrees with the typical prepubertal stage in cattle, as was found in other animal species and in children (Meusy, Dessolle 1975; Flor-Cruz \& Lapwood 1978; Courot et al. 1975).

The level of plasma testosterone in bulls aged 7 to 13 months significantly varies in its mean value as compared to the preceding groups of bulls. The ascertained difference corresponds to the results reported by Flor-Cruz and Lap- 
wood (1978), who, in agreement with our results, report that in the first phase of puberty an increase in PT takes place in the boar, and a further period exhibits a decrease in this hormone. Our further studies agree with this finding of the cited authors, because the level of PT in bulls aged 2 years or more is somewhat lower than in the category of bulls aged 7-13 months. The marked fluctuation in the levels of PT we found in categories of the same age has been reported by other authors as well (Sitarz et al. 1977; Katongole et al. 1971; Smith et al. 1973; Schams et al. 1978; Sundby \& Tollman 1978; Bamberg et al. 1976; and others), who justify the fluctuation of the levels by the seasonal fluctuation of the levels of PT, sexual stimulation, feeding regimen, and the individual rhythm of testosterone incretion.

On the basis of our studies and in agreement with data from literature, one may claim that from the period of puberty bulls cannot be categorized according to the level of plasma testosterone nor according to their sexual activity.

Statistically significant lower levels of PT are ascertained during the prepubertal period, and still lower ones towards the end of the intrauterine development of the fetus without any marked tendency towards a lasting change of level in connection with the approaching birth, differing from values reported in pigs and some other animals.

\section{Hladina plazmatického testosteronu v prenatálním a postnatálním období vývoje býků}

K stanovení testosteronu v krevní plazmě byla použita přímá radioimunologická metoda $s$ testosteronem značkovaným tritiem. V prenatálním období bylo vyšetřeno 44 fétů od 190 . do 288 . dne intrauterinního vývoje. V průměru byly zjištěny hodnoty $0,33 \pm 0,21 \mathrm{ng} / \mathrm{ml}$, bez zřetelného vztahu ke stáŕí vyvíjejícího se plodu. V postnatálním údobí bylo stanovení provedeno u 57 býků 47 až 106 dnů starých a $\mathrm{v}$ průměru bylo zjištěno $0,65 \pm 0,42 \mathrm{ng} \cdot 1^{-3}$ plazmy, u býků $7-13$ měsíců starých $6,64 \pm 5,71 \mathrm{ng} \cdot 1^{-3}$ plazmy, a u býků 2 více let starých $6,28 \pm 4,26 \mathrm{ng} \cdot 1^{-3}$. Rozdíl mezi prủměrnou hodnotou plazmatického testosteronu $\mathrm{v}$ prenatálním údobí $\mathrm{v}$ porovnání se všemi hodnocenými věkovými kategoriemi po narození byl statistiky významný $(P<0,01)$. Také u býčků ve stáŕí 47 až 106 dnů byly prưměrné hodnoty plazmatického testosteronu oproti nálezům u dalších věkových skupin signifikantně nižší $(P<0,01)$. Mezi skupinou býků 7-13 měsíců starých a skupinou 2 a více let starých býkủ rozdíly signifikantní nebyly, i když u mladších zvírat byly hladiny plazmatického testosteronu poněkud vyšší.

Уровень плазменного тестостерона в дородовом и послеродовом периодах развития быков

Для определения тестостерона в кровяной плазме был использован прямой радиоимунологический метод с тестостероном, меченным тритием. Исследования в дородовый период проводились на 44 зародышей со 190 по 288 дней внутриматочного развития. В среднем были установлены величины $0,33 \pm$ $\div 0,21$ мкг/мл без явного отношения к возрасту развивающегося плода. В послеродовый период определение проводилось у 57 быков в возрасте 47-106 
дней и в среднем было установлено $0,65 \pm 0,42$ мкг тестостерона на 1 мл плазмы, у 108 быков в возрасте 7-13 месяцев - 6,64士5,71 мкг на 1 мл и у быков в возрасте 2 года й старше - 6,28 4,26 мкг на 1 мл. Разница между средней величиной плазменного тестостерона в дородовом периоде по сравнению со всеми исследуемыми возрастными категориями послеродового гериода была статистически значимой $(P<0,01)$. Средние величины плаз- менного тестостерона у бычков в возрасте 47-106 дней были по сравнению с величинами последующих возрастных категорий статистически существенно ниже $(\mathrm{P}<0,01)$. Между группой быков $7-13$ месяцев и группой в возрасте 2 года и больше не наблъдалось статистически значимой разницы, хотя у более молодой категории животных были выявлены несколько повышенные уровни плазменного тестпстерона.

\section{References}

BAMBERG, E. - RITTMANNSPERGER, F. - JETTMAR, W. - CHOI, H. S.: Untersuchungen über den Einfluss von Fütterung und Abstammung auf Testosterongehalt im Plasma des Stieres vor und nach dem Sprung. Wiener Tierärzt. Monatsschr., 10, 1976: 294-298.

COUROT, M. - de REVIERS, M. M. - PELLETIER, J.: Variations in pituitary and blood LH during puberty in the male lamb. Relation to time of birth. Ann. Biol. Anim. Biochim. Biophys., 515, 1975: 509-451.

ELLENDORF, F. - PARVIZI, N. - POMERANTZ, D. K. - HARTJEN, A. - KONIG, A. - SMIDT, D. - ELSAESSER, F.: Plasma luteinizing hormone and testosterone in the adult male pig: 24 hour fluctuations and the effect of copulation. J. Endocr., 67, 1975: 403-407.

ENBERGS, H. - KÜPPER, G. - SOMMER, H.: Testosteronkonzentration im Serum von Warmblut-Zuchthengsten unter normalen und Belastungs-bedingungen. Zuchthygiene, 12, 1977: $49-57$.

FLOR-CRUZ, S. V. - LAPWOOD, K. R.: A longitudinal study of pubertal development in boars. Internat. J. Androl., 1, 1978: 317-330.

FOOTE, R. H. - MUNKENBECK, NANCY - GRENE, W. A.: Testosterone and libido in Holstein bulls of various ages. J. Dairy Sci., 59, 1976: 2011-2013.

FOERST, M. G. - CATHIARD, A. M. - BOURGEOIS, J. - GENOUD, J.: Androgenes plasmatiques chez le nourisson normal et premature relation avec la maturation de l'axe hypothalamo-hypophyso-gonadique. Inserm-colloque-endocrinol. sexuelle de la periode perinatale, 1974: $243-244$.

HRUŠKA, K. - NAVRÁTIL, S. - FRÁNEK, M. - PODANÝ, J.: Vliv ejakulace na koncentraci testosteronu v periferní krvi kancủ. Čs. fysiol., 23, 1974: 257.

CHARALAMBOS, S.: Vliv velikosti gonád na některé ukazatele kvality ejakulátů byků. Thesis VSV Brno, 1979, pp 62.

KATTESH, H. G. - KORNEGAY, E. T. - GWAZDAUSKAS, F. C. - KNIGHT, J. W. THOMAS, H. R.: Peripheral plasma testosterone concentration and sexual behavior in young prenatally stressed boars. Theriogenology, 5, 1979: 289-305.

KATONGOLE, C. B. - NAFTOLIN, F. - SHORT, R. V.: Relationships between blood levels of LH and testosterone in bulls and the effect of sexual stimulation. J. Endocr., 50, 1971: 457 to 466 .

KATONGOLE, C. B. - NAFTOLIN, F. - SHORT, R. V.: Seasonal variations in blood luteinizing hormone and testosterone levels in rams. J. Endocr., 60, 1974: 101-106.

MEUSY-DESSOLLE, N.: Variantions quantitatives de la testostérone plasmatique chez le Porc male, de la naissance à l'àge adulte. C. R. Acad. Sc. Paris, t. 281, 1975, serie D, pp. $1875-1878$.

PELARDY, G. - DELOST, P.: Teneurs plasmatiques, testiculaires et surrénailennés en androgénes au cours de la période périnatale et déterminisme de l'hypertestostéronémie néonatale chez le Cobaye. C. R. Acad. Sc., Paris, t. 284, 1977, Serie D: 827-830.

SANFORD, L. M. - SWIERSTRA, E. E. - PALMER, W. M. - HOWLAND, B. E. : The profile of luteinizing hormone and testosterone in the boar. Proc. VIIIth Int. Congr. Anim. Reprod. A. I. Krakow, 1976: 96.

SCHAMS, D. - GOMBE, S. - SCHALLENBERGER, E. - REINHARDT, V. - CLAUS, R.: Relationship of short-term variations of LH,FSH, prolaction and testosterone in peripheral plasma of prepubertal bulls. J. Reprod. Fert., 1, 1978: 145-148. 
SCHANBACHER, B. D. - FORD, J. .J : Seasonal profiles of plasma luteinizing hormone, testosterone and estradiol in the ram. Endocrinology, 99, 1976: 752-757.

SITARZ, N. E. - ERB, R. E. - MARTIN, T. G. - MALVEN, P. V.: Effect of repeated sampling on concentrations of testosterone, LH and prolactin in blood of yearling Angus bulls. Theriogenology, 3, 1977: 151-158.

SMITH, O. W. - MONOGKONPUNYA, K. - HAFS, H. D. - CONVEY, E. M. and OXENDER, W. D.: Blood serum testosterone after sexual preparation or ejaculation or after injections of LH or prolactin in bulls. J. Anim. Sci., 37, 1973: 979-984.

STUPNICKI, R.: Direct radioimmunoassay of progesterone in plasma of farm animals. Endokrinologie, 2, 1975: 145-151.

SUNDBY, A. - TOLLMAN, R.: Plasma testosterone in bulls; seasonal variation. Acta vet. Scand. 19, 1978: $263-268$. 